\title{
Economic Analysis and Crop Equivalent Yield of Citronella (Cymbopogon winterianus) Based Inter-cropping System in Central Plain Zone of Uttar Pradesh, India
}

\author{
Rahul Kumar Mishra*, A.K. Srivastava, Niteesh Kumar Yadav and \\ Deep Chand Chaurasiya \\ Department of Agronomy, C.S. Azad University of Agriculture and Technology, \\ Kanpur, UP, India \\ *Corresponding author
}

\begin{tabular}{|c|}
\hline Keywords \\
\hline $\begin{array}{l}\text { Citronella, Inter- } \\
\text { cropping, Crop oil } \\
\text { equivalent yield, } \\
\text { Net return, LER, B: } \\
\text { C ratio }\end{array}$ \\
\hline Article Info \\
\hline $\begin{array}{l}\text { Accepted: } \\
\text { 06 December } 2017 \\
\text { Available Online: } \\
\text { 10 January } 2018\end{array}$ \\
\hline
\end{tabular}

\section{A B S T R A C T}

An experiment was conducted during rabi season, 2015-16 at Students Instructional Farm (SIF), C.S. Azad University of Agriculture and Technology, Kanpur, Uttar Pradesh to study the economic analysis and crop equivalent yield of citronella (Cymbopogon winterianus) based inter-cropping system in central plain zone of Uttar Pradesh. The experiment was laid out in Randomized block design with 9 treatment of cropping systems with 3 fertility levels i.e. [Sole citronella, Sole Wheat, Sole Mustard, Citronella + Wheat $100 \% \mathrm{RDF}(\mathrm{C}+\mathrm{W} 100 \% \mathrm{RDF})$, citronella + Wheat 75\%RDF (C+W 75\% RDF), citronella + Wheat 50\%RDF (C+W 50\%RDF), citronella + Mustard 100\%RDF (C+M 100\%RDF), citronella + Mustard 75\%RDF $(\mathrm{C}+\mathrm{M}$ 75\%RDF), citronella + Mustard 50\%RDF (C+M $50 \% \mathrm{RDF})]$, were replicated thrice. Results revealed that maximum citronella equivalent oil yield $(28.29 \mathrm{~kg} / \mathrm{ha})$ was obtained in sole citronella, whereas lowest equivalent oil yield was recorded in C+M 50\% RDF (17.50 kg/ha). The highest net income was obtained in $\mathrm{C}+\mathrm{W}$ 75\% RDF (Rs. 44,470.00), whereas lowest in citronella sole. Among the mustard intercropping system highest net return was obtained from the C+M100\% RDF (Rs. 34,605.00) followed by C+M 75\% RDF (Rs. 31,304.00). The highest B: C ratio (benefit: cost ratio) was found in $\mathrm{C}+\mathrm{W} 75 \% \mathrm{RDF}(2.01)$. The lowest $\mathrm{B}$ : $\mathrm{C}$ ratio was observed in Citronella sole treatment (1.36). Land equivalent ratio (LER) was highest in $\mathrm{C}+\mathrm{W} 100 \%$ RDF (1.30) and lowest in control.

\section{Introduction}

Agriculture is an important sector of the Indian economy, accounting $13.4 \%$ of the Nation's GDP. There has been a continuous decline in the share of Agriculture and Allied Sector in the GDP from $14.6 \%$ in $2010-11$ to $13.4 \%$ in 2016-17. India is estimated to produce 275.90 million tonnes of food grains during 2016-17 as compared to 251.57 million tonnes during 2015-16 (Anon., 2016-17). About half of the population still relies on agriculture as its principal source of income and is a source of raw material for a large number of industries. The increasing importance of natural extracts in recent time has opened up new vistas for green revolution beyond their wide spread use as flavors and 
fragrance ingredients. The essential oil bearing plants are playing a major role in commercial production of aromatic oils making India a major partner in the world scenario. It has become a profitable business in agriculture produce and post harvesting processing industry. Presently, India's position in world market is at top in the production of mints, grasses, spices, exotic flowers, roots and woody oil etc. India is engaged in the large scale cultivation of mentha species and does have potential to grow other plants such as citronella, lemon grass, patchouli, vetiver, rose, and palmarosa. Global turnover of essential oil industry is estimated to be around 14 billion USD of which India's share is $20 \%$.

Citronella oil is classified in trade into two types: Ceylon citronella obtained from Cymbopogon nardus is the inferior type, while java citronella oil obtained from Cymbopogon winterianus considered superior type. Citronella oil is a raw material for production of geranial, citronellal, hydroxyl citronella and other similar high value perfumery bases. It is also widely used as a starting material for various aromatic chemicals used in scented soaps, sprays, deodorants, detergent, polishes, mosquito repellents etc. According to FFDC (Fragrance and flavor of development Centre, Govt. of India, Kannauj) the demand of citronella oil is 620 tonnes per year but the production 480 tonnes per year in India. The country facing deficit of 140 tonnes per year (Anon., 2011-2012).

Citronella is a wide row spaced perennial crop. Intercropping is a technique to increase yield, income of farm and risk management by best utilization of resources. For seeking feasibility of inter-cropping, important cereal and oil seed crop like wheat and mustard can be introduced as inter crop with citronella which are in great demand in the country. These crop combinations can also be proved to seek risk coverage under present changing climatic scenario (Shrivastava et al., 2016). Intercropping systems showed improvement in citronella equivalent oil yield (CEOY), net returns, Land equivalent ratio (LER) and Benefit cost ratio (Ansari et al., 2015). The results indicate that different cropping system was found to exhibit significantly variations for Citronella oil equivalent yield and economics of the system. The present experiment was carried out with an object to find out the economic analysis and crop equivalent yield of citronella (Cymbopogon winterianus) based inter-cropping system in central plain zone of Uttar Pradesh.

\section{Materials and Methods}

An experiment was conducted to study the " Economic Analysis and Crop Equivalent Yield of Citronella (Cymbopogon winterianus) Based Inter-cropping System in Central Plain Zone of Uttar Pradesh" was conducted during rabi season, 2015-16 at Students Instructional Farm (SIF), C.S. Azad University of Agriculture and Technology, Kanpur. The experiment was laid out in Randomized block design with 9 treatment of cropping systems with 3 fertility levels i.e. Sole citronella, Sole Wheat, Sole Mustard, Citronella + Wheat $100 \% \mathrm{RDF}$, citronella + Wheat $75 \% \mathrm{RDF}$, citronella + Wheat $50 \% \mathrm{RDF}$, citronella + Mustard 100\%RDF, citronella + Mustard $75 \% \mathrm{RDF}$, citronella + Mustard 50\%RDF, were replicated thrice.

In case of citronella fertilizer i.e. $\mathrm{N}$ : $\mathrm{P}: \mathrm{K}$ (Nitrogen: Phosphorus: Potassium) applied @ 150:80:40 kg/ha for 100\% RDF, 112.5:60:30 $\mathrm{kg} / \mathrm{ha}$ for $75 \% \mathrm{RDF}$ and 75:40:20 for 50\% RDF. In case of wheat application of NPK @ $120: 60: 40 \mathrm{~kg} / \mathrm{ha}$ for $100 \% \mathrm{RDF}, 90: 45: 30$ $\mathrm{kg} / \mathrm{ha}$ for $75 \% \mathrm{RDF}$ and 60:30:20 kg/ha for $50 \%$ RDF. In mustard fertilizer i.e. NPK should be applied at the rate $80: 40: 40 \mathrm{~kg} / \mathrm{ha}$ for $100 \% \mathrm{RDF}, 60: 30: 30 \mathrm{~kg} / \mathrm{ha}$ for $75 \% \mathrm{RDF}$ and 40:20:20 kg/ha for 50\% RDF. The soil of 
experimental field was sandy loam, slightly alkaline in nature with $8.09 \mathrm{pH}$ and $0.22 \mathrm{EC}$. The soil is low in organic carbon and available nitrogen $(260 \mathrm{~kg} / \mathrm{ha})$, medium in available phosphorus $(17.55 \mathrm{~kg} / \mathrm{ha})$ and potash (175 $\mathrm{kg} / \mathrm{ha}$ ). Root slips of Citronella variety BIO-13 were used. After removing upper sheath the root slips was transplanted in line on 30 July, 2010 at a spacing of $60 \times 60 \mathrm{~cm}$. The row ratio of 2:2 was maintained in citronella intercrop plots. Seed of Wheat CV. K- 9107 (Deva) was used @ $100 \mathrm{~kg} / \mathrm{ha}$. The crop was sown with the help of Desi plough in line at a spacing of $20 \mathrm{~cm}$ from row to row. Seed of Mustard CV. Urvashi was used @ 5 kg/ha. The crop was sown with the help of Desi plough at a spacing of $40 \mathrm{~cm}$ from row to row and $15 \mathrm{~cm}$ from plant to plant.

Crop equivalent yield (CEY), Land equivalent ratio (LER), Benefit: Cost ratio (B: $\mathrm{C}$ ratio) was calculated by following formula:

$$
\begin{aligned}
& \text { Intercrop yield }\left(\mathrm{kgha}^{-1}\right) \mathrm{x} \\
& \text { Price of intercrop yield }\left(\mathrm{Rskg}^{-1}\right) \\
& \text { CEY = - } \quad \text { Price of main crop }\left(\mathrm{Rskg}^{-1}\right) \\
& \text { LER of Wheat }=\frac{\text { Yield of citronella in inter cropping }}{\text { Yield of citronella in sole cropping }}+\frac{\text { Yield of wheat in inter cropping }}{\text { Yield of Wheat in sole cropping }} \\
& \text { LER of mustard }=\frac{\text { Yield of citronella in inter cropping }}{\text { Yield of citronellain sole cropping }}+\frac{\text { Yield of mustard in inter cropping }}{\text { Yield of mustard in sole cropping }} \\
& \text { Net return }
\end{aligned}
$$

B: C Ratio $=$

\section{Cost of cultivation}

Net profit in rupees was worked out on hectare basis. Common cost of cultivation as well as treatment wise cost of cultivation was worked out on the rate prevailed during 2015.

The net profit was calculated by subtracting total cost of cultivation from the total returns obtained from grain and oil yield. Value as grain and oil yield was calculated on existing price. The treatment wise cost of cultivation was subtracted from the gross income to get net profit (Rs/ha).

\section{Results and Discussion}

Effect of different RDF and intercropping systems on crop equivalent yield of citronella (oil yield), wheat and mustard

Data on Citronella equivalent oil yield ( $\mathrm{kg} / \mathrm{ha})$ as influenced by cropping systems have been depicted in Table 1. The significantly highest Citronella equivalent oil yield was found in sole citronella $(28.29 \mathrm{~kg} / \mathrm{ha})$ followed by Citronella + wheat $100 \%$ RDF $(25.54 \mathrm{~kg} / \mathrm{ha})$, whereas lowest oil equivalent yield was obtained in $\mathrm{C}+\mathrm{M} 50 \% \mathrm{RDF}(17.50 \mathrm{~kg} / \mathrm{ha})$. The results of the present investigation are in close conformity with the findings of Srivastava et al., (2016), Ansari et al., (2015).

Table.1 Effect of different RDF and intercropping systems on crop equivalent yield of citronella (oil yield), wheat and mustard

\begin{tabular}{|c|c|c|c|c|c|}
\hline Treatment & $\begin{array}{c}\text { Citronella } \\
\text { yield (q/ha) }\end{array}$ & Oil yield (kg/ha) & $\begin{array}{c}\text { Grain yield wheat } \\
(\mathrm{q} / \mathrm{ha})\end{array}$ & $\begin{array}{c}\text { Seed yield mustard } \\
\text { (q/ha) }\end{array}$ & $\begin{array}{c}\text { Oil Equivalent } \\
\text { yield (kg/ha) }\end{array}$ \\
\hline Sole citronella & 35.36 & 28.29 & - & - & 28.29 \\
\hline Sole wheat & - & - & 34.63 & - & - \\
\hline Sole mustard & - & - & & 13.85 & - \\
\hline C+W 100\% RDF & 25.87 & 20.69 & 19.78 & - & 25.54 \\
\hline C+W 75\% RDF & 28.46 & 22.77 & 18.63 & - & 21.72 \\
\hline C+W 50\% RDF & 25.61 & 20.49 & 16.82 & - & 24.70 \\
\hline C+M 100\% RDF & 24.15 & 19.32 & - & 7.91 & 20.59 \\
\hline C+M 75\% RDF & 20.70 & 16.56 & - & 6.59 & 17.50 \\
\hline C+M 50\% RDF & 28.46 & 22.77 & - & 5.60 & \\
\hline
\end{tabular}


Table.2 Effect of different RDF and intercropping systems on Cost of cultivation, Gross returns, Net returns, B: C ratio and LER

\begin{tabular}{|c|c|c|c|c|c|}
\hline Treatments & $\begin{array}{c}\text { Cost of cultivation } \\
\text { (Rs/ha) }\end{array}$ & $\begin{array}{c}\text { Gross } \\
\text { returns } \\
\text { (Rs/ha) }\end{array}$ & $\begin{array}{c}\text { Net returns } \\
\text { (Rs/ha) }\end{array}$ & $\begin{array}{c}\text { B: C } \\
\text { ratio }\end{array}$ & LER \\
\hline Citronella sole & $14,326.00$ & $33,840.00$ & $19,514.00$ & 1.36 & 1.00 \\
\hline Wheat sole & $27,600.00$ & $69,508.00$ & $41,908.00$ & 1.51 & 1.00 \\
\hline Mustard sole & $19,206.00$ & $51,938.00$ & $32,732.00$ & 1.70 & 1.00 \\
\hline C+W 100\% RDF & $22,341.00$ & $65,535.00$ & $43,149.00$ & 1.93 & 1.30 \\
\hline C+W 75\% RDF & $21,581.00$ & $65,018.00$ & $43,437.00$ & 2.01 & 1.12 \\
\hline C+W 50\% RDF & $20,280.00$ & $57,409.00$ & $43,129.00$ & 1.84 & 1.20 \\
\hline C +M 100\% RDF & $18,242.00$ & $52,847.00$ & $34,605.00$ & 1.89 & 1.25 \\
\hline C +M 75\% RDF & $17,646.00$ & $44,585.00$ & $26,939.00$ & 1.52 & 1.05 \\
\hline C+M 50\% RDF & $17,055.00$ & $48,360.00$ & $31,304.00$ & 1.83 & 1.20 \\
\hline
\end{tabular}

Note- In intercropping system gross return also include cost of cultivation of citronella oil.

Effect of different RDF and intercropping systems on cost of cultivation, gross returns, net returns, B: C ratio and LER

The economics of sole crop and inter-crops with different recommended doses of fertilizer (100\%RDF, $75 \% \mathrm{RDF}$ and $50 \% \mathrm{RDF})$ in rabi season was worked out in the form of cost of cultivation, Gross return, net profit and benefit cost ratio and LER presented in Table 2.

Treatment wise costs of cultivation were calculated except citronella because the crop is well established. It is clear from the Table 2 that the cost of cultivation is highest in sole wheat (Rs. 27,600.00) followed by $\mathrm{C}+\mathrm{W} 100 \% \mathrm{RDF}$ (Rs. 22,341.00), C+W 75\% RDF (Rs. 21,581.00) and C+W 50\%RDF (Rs. 20,280.00), whereas lowest cost of cultivation was recorded in sole citronella (Rs. 14,326.00).

Among the mustard intercropping cost of cultivation of sole mustard (Rs.19,206.00), C+M 100\% RDF (Rs. 18,242.00), C+M 75\% RDF (Rs. 17,646.00) and C+M 50\% RDF (Rs. 17,055.00) respectively. The data computed regarding gross income showed that the highest gross income was recorded in sole wheat (Rs. 69,508.00) followed by C+W 100\% RDF (Rs. 65,535.00), C+W 75\% RDF (Rs.65,018.00),
C+W 50\% RDF (Rs. 57,409.00), C+M 100\% RDF (Rs. 52,847.00), mustard sole (Rs. 51,938.00), C+M 50\% RDF (Rs. 48,360.00), C+M75\% RDF (Rs. 44,585.00) and the lowest gross income found in sole citronella (Rs.33,840.00) treatment. Among all the treatment highest net income was obtained in C+W 75\% RDF (Rs. 44,470.00) followed by C+W 100\% RDF (Rs. 44,227.00), Among sole treatment, highest net return was obtained from wheat sole treatment (Rs. 41,908.00) followed by mustard sole (Rs. 32,732.00) and lowest in sole citronella (Rs. 19,514.00).

In mustard intercropping system highest net return was obtained from the $\mathrm{C}+\mathrm{M} 100 \% \mathrm{RDF}$ (Rs. 34,605.00) followed by $\mathrm{C}+\mathrm{M}$ 75\% RDF (Rs. 31,304.00) and C+M 50\% RDF (Rs. 26,939.00) similar findings also observed by Pandey et al., (1999) and Singh et al., (2008). The highest $\mathrm{B}: \mathrm{C}$ ratio was found in $\mathrm{C}+\mathrm{W} 75 \%$ RDF (2.01) followed by $\mathrm{C}+\mathrm{W} 100 \% \mathrm{RDF}$ (1.93), C+M 100\% RDF (1.89), C+W 50\% RDF (1.84), C+M 50\% RDF (1.83), mustard sole (1.70), C+M 75\% RDF (1.52) and sole wheat treatment (1.51) respectively. The lowest B: C ratio was observed in Citronella sole treatment (1.36) similar finding are also observed by Behera et al., (2015), Sharma et al., (2015), Singh (2003) and Mani ram et al., 
(2015). The highest LER found in C+W $100 \%$ RDF (1.30) followed by $\mathrm{C}+\mathrm{M} 100 \% \mathrm{RDF}$ (1.25), $\mathrm{C}+\mathrm{W} 50 \% \mathrm{RDF}(1.20), \mathrm{C}+\mathrm{M} 50 \% \mathrm{RDF}$ (1.20), $\mathrm{C}+\mathrm{W} 75 \%$ RDF (1.12), C+M 75\% RDF (1.05) and lowest LER found in sole citronella, sole wheat and sole mustard (1.00) respectively. The results are in accordance with the findings of Mani ram et al., (2015) and Srivastava et al., (2007).

\section{References}

Anonymous. 2011-12. Fragrance and flavour of development centre, Govt. of India, Kannuj.

Anonymous. 2016-17. Economic survey of India.

Ansari, M. H., B. K. Verma, M. A. Ansari, D. Mishra, A. K. Srivastava, N. Khan and Saquib, M. 2015. Impact of cropping pattern on growth, yield attributes and system productivity of citronella (Citronella winterianus) pulses intercropping system in Central India. Indian Journal of Agricultural Sciences, 85(3).

Behera, M. S., D. K. Kundu, S. Satpathy, A. Singh, A. K. Jha and Nayak, R. K. 2015. Scope and opportunity of intercropping of medicinal and aromatic plants with sisal plantation. International Journal of Tropical Agriculture, 33(2): 1771-1773.

Maniram, A. K. Srivastava, Tomar, K. Ravindra, B. Puspendra and Shive 2015. The response of different fertilizer doses on sole citronella (Cymbopogon winterianus) and intercropping with maize (Zea mays) and bajra (Pennisetum typhoides). Progessive Research - An International Journal, 10(special-V): 2612-2615.
Pandey, B. K., M. D. Pandey, P. J. Mishra and Sinoh, R. 1999. Response of direction and methods of sowing wheat in pure and intercropping. Madras Agricultural Journal. 86(7/9): 389-391.

Sharma, P. K., M. Hazarika, D. Sharma, P. Saikia, P. Neog, R. Rajbongshi, N. Kakati, M. Bhattacharjee and Rao, S. 2015. Effect of foliar application of potassium on yield, drought tolerance and rain water use efficiency of toria under rainfed upland situation of Assam. Indian Journal of Dryland Agriculture Research and Development, 30(1): 55-59.

Singh, M. 2003. Compatibility of Legume, an aromatic crop and a cereal as intercrops in Palmarosa (Cymbopogon martini staff.). Journal of Spices and Aromatic Crops, 12(2): 190-193.

Singh, S., O. N. Yadav, R. K. Chauhan and Lohani, H. 2008. Effect of different planting geometry on growth, yield and quality of citronella (Cymbopogan winterianus). Journal of Medicinal and Aromatic Plant Sciences, 30(3): 267-269.

Srivastava, A. K., V. Singh, V. K. Verma, S. Chaudhary, R. Pyare, B. K. Verma and Parihar G. S. 2016. Economic viability of citronella (Cymbopogon winterianus) based inter-Cropping system in central plain zone of Uttar Pradesh. International Research Journal of Natural and Applied Sciences, 3(4): 136-150.

Srivastava, R. K., J. S. Bohra and Singh, R. K. 2007. Yield advantage and reciprocity functions of wheat (Triticum aestivum) + Indian mustard (Brassica juncea) intercropping under varying row ratio, variety and fertility level. Indian Journal of Agricultural Sciences, 77(3): 139-144.

\section{How to cite this article:}

Rahul Kumar Mishra, A.K. Srivastava, Niteesh Kumar Yadav and Deep Chand Chaurasiya. 2018. Economic Analysis and Crop Equivalent Yield of Citronella (Cymbopogon winterianus) Based Inter-cropping System in Central Plain Zone of Uttar Pradesh. Int.J.Curr.Microbiol.App.Sci. 7(01): 783-787. doi: https://doi.org/10.20546/ijcmas.2018.701.095 